\title{
E-Learning Berbasis Flipped Classroom pada Mata Pelajaran Matematika
}

\section{A.A Gde Agung Dwi Angga Nirarta ${ }^{1 *}$, I Nyoman Jampel ${ }^{2}$, I Komang Sudarma ${ }^{3}$}

1,2,3 Universitas Pendidikan Ganesha, Singaraja, Indonesia

\section{ART I CLE INFO}

Article history:

Received June 05, 2021

Revised June 09, 2021

Accepted July 09, 2021

Available online July 25, 2021

\section{Kata Kunci:}

Pengembangan, E-Learning Berbasis Flipped Classroom

Keywords:

Development, E-Learning Based

Flipped Classroom

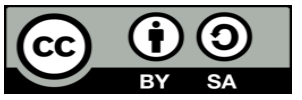

This is an open access article under the CC BY-SA license.

Copyright (C) 2021 by Author. Published by Universitas Pendidikan Ganesha.

\begin{abstract}
A B S T R A K
Pada saat pandemi telah terjadi penurunan hasil belajar matematika dikarenakan guru terlalu sering menggunakan model pembelajaran teacher center dalam proses pembelajaran. Tujuan dari penelitian ini adalah untuk menguji kelayakan e-learning berbasis flipped classroom pada mata pelajaran matematika diera covid-19. Penelitian ini menggunakan model ADDIE sebagai model penelitian. Subjek penelitian yang digunakan dalam penelitian ini adalah para ahli dan siswa. Metode pengumpulan yang digunakan adalah wawancara, observasi, dan kuesioner. Sedangkan teknik pengumpulan data yang digunakan adalah teknik analis data deskriptif kualitatif dan deskriptif kuantitatif. Hasil dari penelitian pengembangan ini adalah pertama desain pengembangan model e-learning berbasis flipped classroom pada mata pelajaran matematika meliputi analisis, desain, pengembangan, implementasi, dan evaluasi. Kedua hasil uji validitas dari para ahli dan subjek uji coba produk mendapatkan predikat valid berdasarkan: hasil review ahli isi pembelajaran dengan kualifikasi sangat baik (93\%), hasil review ahli desain pembelajaran dengan kualifikasi baik (89\%), hasil review ahli media pembelajaran dengan kualifikasi sangat baik (94\%), hasil uji coba perorangan dengan kualifikasi baik (80\%), dan hasil uji coba kelompok kecil dengan kualifikasi baik (87\%), serta hasil uji coba lapangan dengan kualifikasi baik (84\%). Ketiga hasil efektivitas model pembelajaran e-learning berbasis flipped classroom pada mata pelajaran matematika mendapatkan hasil efektif berdasarkan hasil uji efektivitas dengan hasil 10,65 dengan $t_{\text {hitung }}>t_{\text {tabel }}$ dengan taraf signifikasi 5\%. Jadi berdasarkan hasil penelitian tersebut, pengembangan e-learning berbasis flipped classroom layak digunakan dalam pembelajaran matematika dan dapat meningkatkan hasil belajar siswa.
\end{abstract}

\begin{abstract}
A B S T R A C T
During the pandemic, there has been a decline in mathematics learning outcomes because teachers use the teacher center learning model too often in the learning process. The purpose of this study was to test the feasibility of e-learning based on flipped classroom in mathematics subjects in the covid-19 era. This study uses the ADDIE model as the research model. The research subjects used in this study were experts and students. The collection methods used are interviews, observation, and questionnaires. While the data collection techniques used were descriptive qualitative and quantitative descriptive data analysis techniques. The results of this development research are the first to design the development of an e-learning model based on the flipped classroom on mathematics subjects including analysis, design, development, implementation, and evaluation. Both the results of the validity test from the experts and the product test subjects received valid predicates based on: the results of the review of learning content experts with very good qualifications (93\%), the results of the review of learning design experts with good qualifications (89\%), the results of the reviews of learning media experts with very good qualification (94\%), individual trial results with good qualifications (80\%), and small group trial results with good qualifications (87\%), and field trial results with good qualifications (84\%). The three results of the effectiveness of e-learning based on flipped classroom learning model in mathematics subjects get effective results based on the results of the effectiveness test with the results of 10.65 . with $t_{\text {count }}>t_{\text {table }}$ with a significance level of $5 \%$. So based on the results of these studies, the development of e-learning based on flipped classroom is feasible to use in learning mathematics and can improve student learning outcomes.
\end{abstract}

\section{PENDAHULUAN}

Pandemic COVID-19 sedang melanda dunia, yang mengakibatakan banyak terjadi perubahan segala bidang kehidupan manusia. Salah satu bidang yang mengalami perubahan adalah bidang pendidikan. perubahan yang terjadi dalam bidang pendidikan adalah segala kegiatan yang melibatkan orang banyak seperti seminar, lokakarya, workshop dan study banding ditunda bahkan di hentikan serta pembelajaran yang semuala tatap muka harus digantikan dengan pembelajaran daring (Mishra et al., 2020; Oyedotun, 2020; Patricia, 2020; Sahu, 2020). Pembelajaran daring memberikan kesempatan siswa 
untuk belajar lebih mandiri tanpa ada batas ruang serta waktu (Hwang et al., 2020; Kkese, 2020; LageCala et al., 2020). Pembelajaran online akan membantu peserta didik untuk memahami materi yang bersifat abstrak, mengembangkan pembelajaran kolaborasi, penalaran dan kegiatan pemecahan masalah (Arnott \& Yelland, 2020). Pembelajaran online adalah salah satu solusi yang dapat dilakukan untuk mencegah penyebaran covid-19 dan mengurangi kecemasan peserta didik dalam menghadapi perubahan kehidupan secara tiba-tiba. (Hussein et al., 2020). Pembelajaran daring adalah pembelajaran online, yang sangat membutuhkan kemampuan pendidik dan peserta didik, karena adanya kemampuan dalam menggunakan teknologi akan sangat membantu membuat suasana pembelajaran yang lebih baik (Andel et al., 2020). Selain kemampuan tentunya pembelajaran online juga harus memperhatikan kondisi finansial dari peserta didik dan sarana dan prasarana yang menunjang pembelajaran online (Rusli et al., 2020). Jadi adanya pembelajaran daring akan memberikan dampak positif dalam proses pembelajaran daring memberikan dampak positif dalam proses pembelajaran. Salah satu media pembelajaran daring yang dilakukan adalah pembelajaran e-learning.

E-learning adalah segala proses pembelajaran yang dibantu dengan internet dalam berbagai interaksi pembelajaran(Sadikin \& Hamidah, 2020). Oleh sebab itu e-learning menjadi salah satu model pembelajaran yang paling banyak di gunakan dalam masa covid-19 ini (Kaur et al., 2020; Looi, 2021). Hal ini mengingat (Niswati et al., 2017). E-learning mewadahi keterlibatan siswa, pengembangan pengetahuan dan keterampilan siswa (Zotov et al., 2021). Adanya pembelajaran menggunakan e-learning akan membantu siswa untuk belajar lebih aktif dalam proses pembelajaran (Elyas, 2018), Kelebihan $e$ learning sendiri yaitu lebih mengurangi biaya, serta flexibilitas waktu yang lebih baik(Leonard \& Mutia, 2013). Manfaat yang diberikan e-learning jauh lebih banyak, yaitu meningkatkan partisipasi siswa, meningkatkan kemandirian siswa, meningkatkan kualitas pendidikan, dan meningkatkan kemampuan teknologi dari guru(Setyoningsih, 2015). Keberhasilan pembelajaran dengan media e-lerning sangat dipengaruhi oleh fasilitas pendukung pembelajaran (Amin et al., 2021). Untuk mengwujudkan pembelajaran dengan e-learning yang berkulitas dibutuhkan sebuah persiapan serta membuat e-learning lebih efisien (Kim \& Park, 2021). Jadi, adanya e-learning akan memberikan solusi yang baik terhadap pembelajaran jarak jauh saat ini, sistem e-learning yang berkualitas akan sangat mebrika kepuasan kepda siswa dalam proses pembelajaran serta dapat meningkatkan pengetahuannya.

Namun dalam prakteknya di lapangan berkata lain. Guru lebih masih sulit dalam menggunakan model pembelajaran ini. Faktor yang menyebabkannya adalah jaringan internet dan kurangnya dalam sosialisasi penggunaan e-learning. Pembelajaran e-learning memiliki beberapa kendala yaitu kurangnya interaksi siswa dan guru, proses pembelajaran cenderung menjadi ke pelatihan, dan tidak semua tempat memiliki internet(Albab, 2020). Siswa yang tidak memiliki motivasi belajar juga akan membuat pembelajaran terhambat, serta kurangnya penggunaan teknologi seperti komputer juga akan menghambat pembelajaran e-learning (Muna \& Hadisi, 2015). Faktor inilah yang akan menyebabkan rendahnya motivasi, minat, dan hasil belajar siswa. Kondisi ini sesaui dengan hasil analisis awal yang dilakukan diperoleh hasil informasi bahwa pencapaian hasil belajar siswa terhadap mata pelajaran Matematika belum maksimal. Beliau mengatakan siswa masih menghafal dalam proses belajar matematika. Selain itu Siswa hanya bergantung pada guru dalam mencari referensi soal atau referensi materi. Sedangkan berdasarkan data analisis yang didapat rata-rata nilai hasil belajar Matematika yang ditemukan bahwa untuk kelas VIII. 1 dan Kelas VIII.11 masih banyak siswa yang belum mencapai KKM, dengan persentase untuk Kelas VIII.1 sebanya 53,33\% siswa belum mencapai KKM meskipun untuk nilai rata-rata kelas mereka sudah melampaui KKM, sedangkan untuk kelas VIII. 11 sebanyak 68,96\% siswa belum mencapai KKM. Bisa dilihat juga bahwa kelas VIII. 2 adalah satu kelas yang banyak siswanya telah melampaui KKM dengan persentase sebanyak $84,38 \%$, akan tetapi masih ada siswa yang belum mencapai KKM di kelas VIII. 2. Dari hasil observasi dan wawancara yang dilakukan, diduga kurang maksimalnya pencapaian hasil belajar disebabkan karena belum tepatnya penggunaan model pembelajaran yang sesuai dengan karakteristik siswa, masih maraknya penggunaan metode ceramah dan hafalan. Melihat masih banyaknya siswa yang belum memenuhi KKM dalam pelajaran matematika maka di perlukan upayaupaya untuk meningkatkan pemahaman siswa agar tidak perlu lagi menghafal. Dari hasil observasi itu juga ditemukan bahwa pembelajaran matematika di SMP N 2 Singaraja dilakukan secara tatap muka di ruang kelas dengan dukungan sarana dan prasarana yang memadai. Namun, pemanfaatan dan pengelolaan sarana dan prasarana tersebut belum optimal.

Paparan tersebut menunjukkan kesenjangan antara kondisi nyata dengan kondisi yang diharapkan, jika hal tersebut tidak ditindak lanjuti maka akan berdampak pada rendahnya motivasi, minta serta hasil belajar siswa. Oleh sebab itulah salah satu solusi yang ditawarkan adalah dengan pengembangan model model e-learning berbasis flipped classroom. Model ini sangat terkenal karena membuat siswa menjadi mandiri dalam proses pembelajaran sekaligus mengurangi pola Teacher centered. Flipped classroom adalah pembelajaran yang biasanya diselesaikan di kelas sekarang bisa diselesaikan di 
rumah (Subagia, 2017). Flipped classroom adalah salah satu pendekatan pedagogis, yang kegiatannya disusun lebih efektif dalam memberikan pendidikan lebih banyak interaksi tatap muka dengan siswa dan dapat memperbesar fleksibilitas jadwal pembelajaran untuk meningkatakan hasil belajar(Ahmed \& Indurkhya, 2020), dapat meningkatkan efikasi diri siswa, serta siswa dapat mengatur dirinya dengan baik sehingga terjadi peningkatan kinerja (Chiu Lin Lai \& JenHwang, 2016). Selain itu itu e-learning berbasis flipped classroom memiliki keunggulan yaitu. E-learning berbasis flipped classroom bisa menjadi awal bagi guru untuk mulai menggunakan model e-learning dalam proses pembelajaran.

Beberapa penelitian yang sudah dilakukan sebelumnya, penelitian yang menyatakan bahwa terdapat peningkatan hasil belajar yang signifikan sebelum dan sesudah menggunakan model flipped classroom (Latif et al., 2017; Sukayanti et al., 2018) Penelitian yang menyatakan bahwa hasil efektif pada penelitian The flipped classroom: for active, effective and increased learning - especially for low achievers hal ini dapat dilihat dari siswa yang aktif dalam pembelajaran, motivasi siswa yang meningkat karena pengguna media sebagai alat dukung. Sehingga penggunaan model e-learning berbasis flipped classroom pada penelitian ini bisa meningkatkan hasil belajar peserta didik (Nouri, 2016). Penelitian yang menyatakan bahwa pembelajaran model e-learning berbasis flipped classroom efektifitas hal ini dilihat dari penggunaan waktu yang efisien, penggunaan pembelajaran berbasis masalah meningkatkan interaksi siswa dan guru, dan membuat siswa menjadi mandiri dalam belajar sehingga penggunaan model $e$ learning berbasis flipped classroom bisa meningkatkan hasil belajar peserta didik (Arnold-Garza, 2014). Penelitian yang menyatakan bahwa model e-learning dapat meningkatkan hasil belajar peserta didik, pelaksanaan model e-learning yang baik, meningkatkan motivasi peserta didik dalam belajar dan mendapatkan respons yang positif dari peserta didik. Sehingga penggunaan model e-learning berbasis fliped classroom pada penelitian ini bisa meningkatkan hasil belajar peserta didik (Aeni et al., 2017). Sesuai paparan di atas, peneliti memandang perlu adanya model pembelajaran yang inovatif dan dapat membantu siswa agar mandiri dalam pembelajaran serta agar model teacher center dapat di kurangi. Sehingga perlu adanya pengembangan e-learning berbasis flipped classroom Pada Siswa Kelas VIII Mata Pelajaran Matematika di SMP N 2 Singaraja. Model pembelajaran ini memiliki ciri-ciri: mudah digunakan, guru dapat dengan mudah membuat bahan pembelajaran, pembelajaran yang dilaksanakan dibalik menjadi pemberian materi secara online, dan penugasan secara tatap muka. Oleh sebab itu tujuan dari penelitian ini adalah Untuk (1) Mengetahui Desain Pengmbangan E-Learning berbasis Flipped Classroom, (2) Untuk Mengetahui Validitas E-Learning berbasis Flipped classroom beserta media pendukung berupa video pembelajaran dan handout, dan (3) Untuk mengetahui efektivitas E-Learning berbasis Flipped classroom beserta media pendukung berupa video pembelajaran dan handout.

\section{METODE}

Penelitian yang akan dilaksanakan adalah penelitian pengembangan atau bisa dikenal dengan research and development (R\&D). Research and development (R\&D) sendiri adalah strategi dalam mengembangkan suatu produk penelitian, Borg \& Gall (Purnama, 2013: 20) selain itu menurut Seels \& Richery (dalam Setyosari, 2012) penelitian pengembangan adalah sebuah kajian dibuat secara sistematik untuk merancang, mengembangkan, dan mengevaluasi penelitian pembelajaran yang harus memenuhi kriteria konsisten dan efektif. Penelitian pengembangan ini dilaksanakan pada siswa kelas VIII SMP N 2 Singaraja. Subjek pada penelitian ini adalah 1 ahli isi mata pelajaran, 1 ahli desain pembelajaran, 1 ahli media pembelajaran, 3 siswa untuk uji coba perorangan, 9 siswa untuk uji coba kelompok kecil, dan 1 kelas VIII untuk uji lapangan, serta uji efektivitas. Model ADDIE merupakan salah satu model desain materi pembelajaran yang sistematik. ADDIE terdiri dari lima tahapan yaitu, tahap analisis (analysis) yaitu tahap untuk menganalisis keseluruhan kegiatan pembelajaran. Tahap perancangan (design) yaitu tahap untuk mendesain suatu pembelajaran serta mendesain metode evaluasi, Tahap pengembangan (development) adalah tahap mulai mengerjakan rancangan yang telah dibuat. Tahap implementasi (implementation) adalah tahap penerapan produk pengembangan yang telah dibuat dan diuji. Tahap evaluasi (evaluation) adalah tahap uji formatif dan sumatif (Tegeh et al., 2014) Pemilihan model ADDIE sendiri dalam penelitian ini dikarenakan model ADDIE adalah model pengembangan yang terstruktur sistematis, namun memiliki tahapan yang sederhana. Selai itu model ini membuat peneliti memiliki kesempatan dalam melaksanakan evaluasi dan revisi secara terus menerus. Sehingga hasil dari pengembangan ini valid dan reliabel.

Pada penelitian ini menggunakan dua metode dalam pengumpulan datanya, yaitu metode pencatatan dan metode kuesioner. Instrumen yang digunakan juga adalah lembar pencatatan dan lembar kuesioner. Lembar pencatatan dokumen pada penelitian ini digunakan untuk mengumpulkan dokumendokumen terkait dalam perancangan bangun e-learning berbasis flipped classroom dan melakukan pencatatan secara sistematis apabila diperlukan. Hasil dari pencatatan dokumen ini dibentuk berupa 
laporan pengembangan produk e-learning berbasis flipped classroom secara ringkas. Lembar kuesioner pada penelitian ini merupakan hasil dari adaptasi kuesioner milik (Tegeh \& Jampel, 2017) serta adaptasi dari kuesioner (Darmawan, 2014), (Prawiladilaga, 2015) dan (Mahadewi, 2006) yang digunakan untuk mengukur validitas produk yang dikembangkan dari hasil review ahli isi pembelajaran, ahli media pembelajaran, ahli desain pembelajaran, dan tanggapan siswa saat uji coba perorangan, dan kelompok kecil. Adapun kisi-kisi instrumen kuesioner validitas e-learning berbasis flipped classroom dapat disajikan pada Tabel 1, 2, 3 dan 4.

Tabel 1. Kisi-kisi Instrumen Ahli Isi Mata Pelajaran

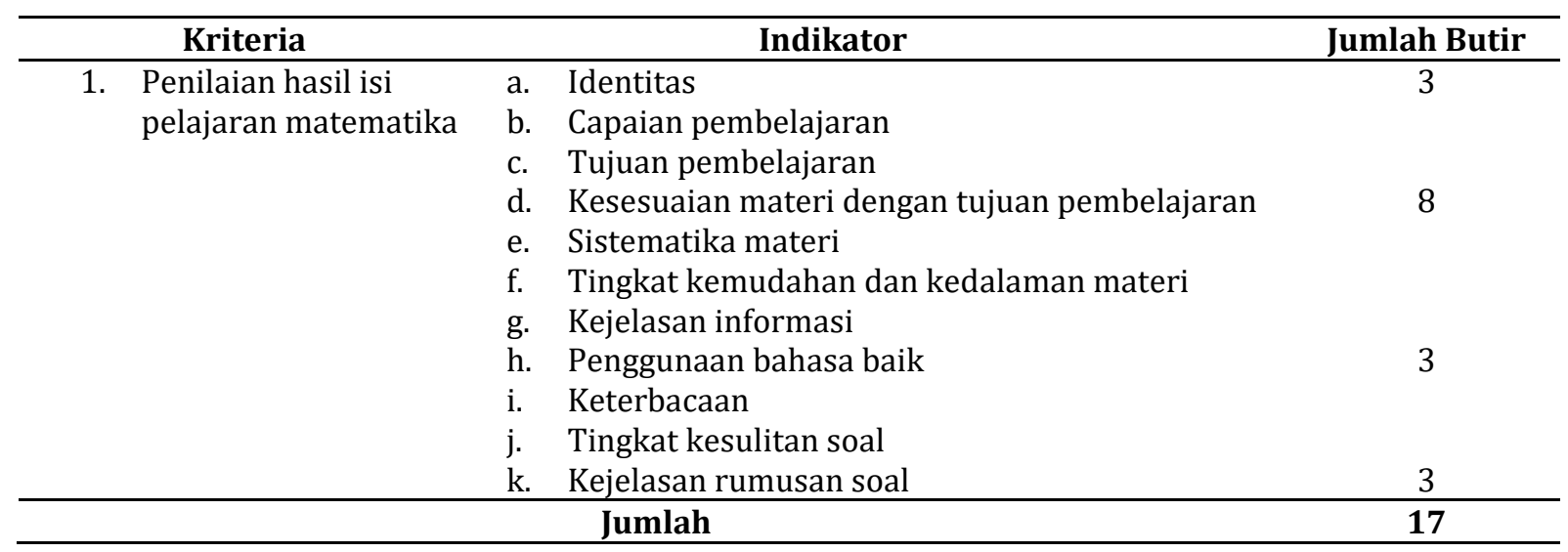

Tabel 2. Kisi-kisi Instrumen Ahli Media Pembelajaran

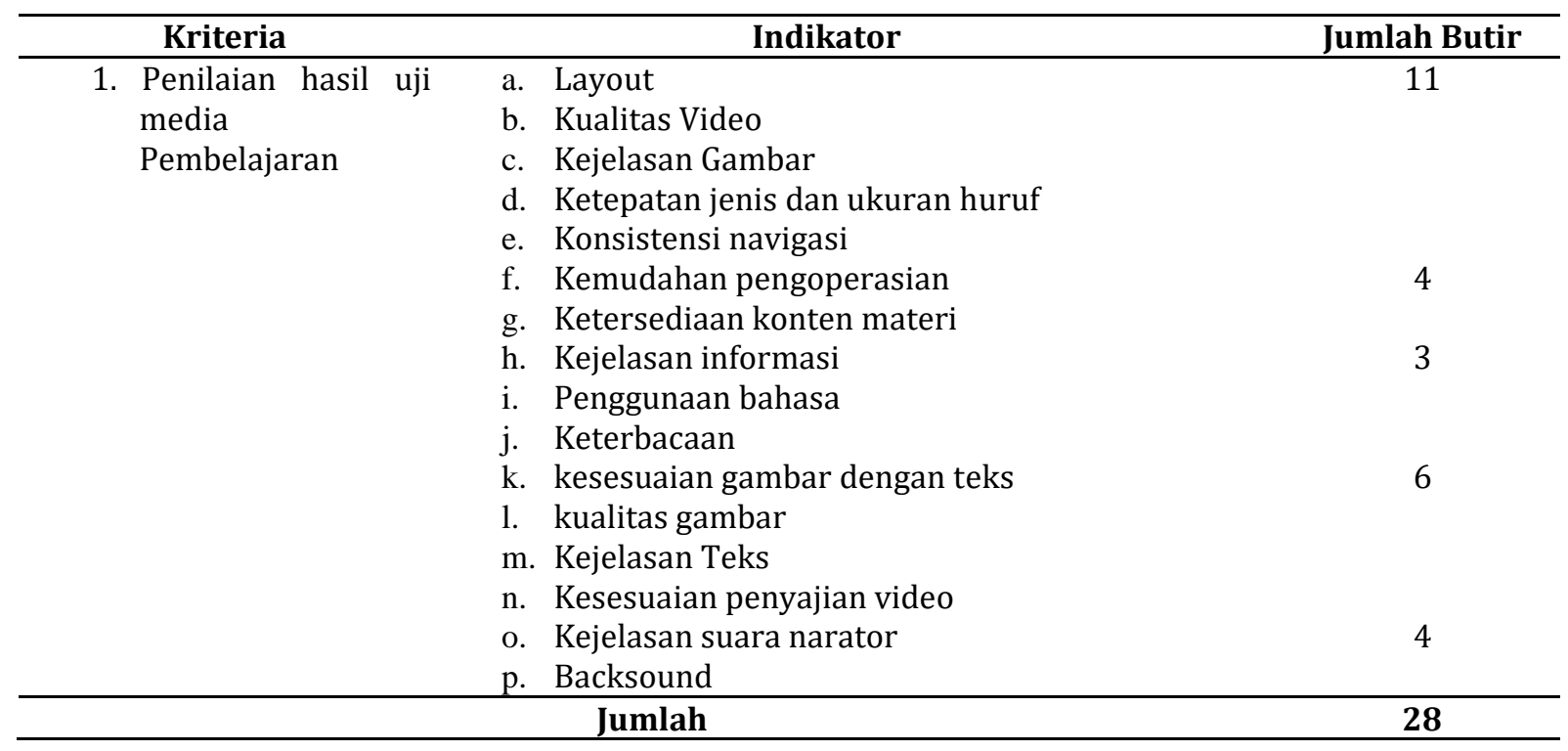

Tabel 3. Kisi-kisi Instrumen Ahli Desain Pembelajaran

\begin{tabular}{lllc}
\hline \multicolumn{1}{c}{ Kriteria } & \multicolumn{1}{c}{ Indikator } & Jumlah Butir \\
\hline 1. & Penilaian hasil uji & 1. & Identitas \\
desain & 2. & Kejelasan informasi & 4 \\
Pembelajaran & 2. & Kompetensi yang ingin dicapai & 9 \\
& 3. & Kelengkapan Media & \\
& 4. & Kejelasan petunjuk belajar & \\
& 5. & Kejelasan rancangan belajar \\
& 6. & Ketersediaan dukungan bahan ajar \\
& 7. & Ketersediaan pembelajaran tatap muda dan online \\
& 8. & Relensi soal \\
& 9. & Ketersediaan evaluasi pembelajaran & 4 \\
\hline
\end{tabular}


Tabel 4. Kisi-kisi Instrumen Uji Coba Perorangan, dan Uji Coba Kelompok Kecil

\begin{tabular}{|c|c|c|}
\hline Kriteria & Indikator & Jumlah butir \\
\hline \multirow[t]{2}{*}{$\begin{array}{l}\text { 1. Penilaian hasil Uji } \\
\text { Coba Produk }\end{array}$} & $\begin{array}{ll}\text { a. } & \text { Kemudahan penggunaan } \\
\text { b. } & \text { Kemenarikan } \\
\text { c. } & \text { Kesesuaian materi } \\
\text { d. } & \text { Ketetapan isi } \\
\text { e. } & \text { Bahasa } \\
\text { f. } & \text { Tugas } \\
\text { g. } & \text { Soal yang ditampilkan } \\
\text { h. } & \text { Motivasi belajar } \\
\end{array}$ & 17 \\
\hline & JUMLAH & 27 \\
\hline
\end{tabular}

Teknik analisis yang akan digunakan pada penelitian ini adalah teknik analis deskriptif kuantitatif, teknik analisis deskriptif kualitatif, dan teknik analisis statistik inferensial. Teknik analisis kualitatif menurut (Agung, 2017) adalah teknik analisis yang menitik beratkan kepada mengolah data berupa kata atau kalimat sehingga akan memperoleh simpulan umum. Penggunaan dari analisis deskriptif kualitatif untuk mengolah data komentar atau saran dari para ahli uji dan dari uji produk. Teknik analisis kuantitatif menurut (Agung, 2017) adalah teknik analisis yang menitik beratkan kepada angka-angka atau persentase. Pada penelitian ini, analisis deskriptif kuantitatif digunakan untuk mengolah data penelitian yang diperoleh dari angket dalam bentuk skor. Sedangkan untuk dapat mengambil keputusan digunakan ketetapan yang disajikan pada Tabel berikut.

Tabel 5. Konversi Tingkat Pencapaian dengan Skala 5

\begin{tabular}{ccc}
\hline Tingkat Pencapaian & Kualifikasi & Keterangan \\
\hline $90-100$ & Sangat baik & Tidak perlu direvisi \\
$75-89$ & Baik & Sedikit direvisi \\
$65-79$ & Cukup & Direvisi secukupnya \\
$55-64$ & Kurang & Banyak hal yang direvisi \\
$1-54$ & Sangat Kurang & Diulangi membuat poduk \\
\hline
\end{tabular}

Sedangkan untuk analisis statistik inferensial menurut (Agung, 2017) adalah cara pengolahan data untuk menguji hipotesis yang telah dibuat dan hasil kesimpulan dapat ditarik dari hasil uji hipotesis. Dala uji analisis statistik inferensial ini menggunakan pre-tes dan post-tes dalam mendapatkan data

\section{HASIL DAN PEMBAHASAN}

Hasil

Hasil dalam penelitian ini akan dibahasa menjadi tiga bagian yaitu: (1) Mendeskripsikan Desain Pengembangan E-Learning berbasis Flipped Classroom, (2) Mendeskripsikan Validitas E-Learning berbasis Flipped classroom beserta media pendukung berupa video pembelajaran dan handout, dan (3) Mendeskripsikan efektivitas E-Learning berbasis Flipped classroom beserta media pendukung berupa video pembelajaran dan handout. Desain Pengembangan model pembelajaran e-learning berbasis flipped classroom ini dikembangkan dengan model penelitian Pengembangan ADDIE yang terdiri dari lima tahapan yaitu: (1) Tahapan pertama adalah analisis (analiyze). Pada tahapan ini dilakukan observasi menyeluruh baik kepada siswa maupun guru dan lingkungan sekolah. Selain hal tersebut juga dilakukan wawancara terhadap guru guna mengetahui masalah-masalah yang dihadapi guru selama mengajar. (2) Tahapan kedua adalah perancangan (design). Pada taha ini dilakukan perancangan e-learning yang akan dibuat meliputi, perancangan RPP, Instrumen penilaian, perancangan flowchart dan storyboard baik itu untuk e-learning maupun media, dan pemilihan software yang akan digunakan. Dalam e-learning berbasis flipped classroom ini akan menggunakan beberapa software yaitu wordpress dengan berbantuan tutor LMS sebagai aplikasi e-learning, video scribe dengan dibantu Adobe primier pro CC sebagai aplikasi pembuat video pembelajaran, dan sofware terakhir adalah microsoft office word 365 untuk membuat media handout. (3) Tahapan ketiga adalah pengembangan (development), pada tahapan ini kegiatan yang dilaksanakan yaitu pembuatan produk berupa aplikasi e-learning dengan wordpress dan media berupa video serta handout dari wujud desain menjadi produk jadi sesuai dengan flowchart dan storyboard yang 
telah dibuat berdasarkan materi dari sumber belajar seperti, buku paket matematika dan internet. (4) Tahapan keempat adalah implementasi (implementation). Pada tahapan ini akan melaksanakan implementasi model e-learning. implementasi yang akan dilaksanakan untuk menguji validitas produk. Serta pada tahap ini akan dilaksanakan uji pre-tes dan post-tes. (5) tahapan terakhir adalah evaluasi (evaluation). Pada tahapan ini akan dilaksanakan evaluasi atau penilaian terhadap itu e-learning berbasis fliped classroom yang telah dikembangkan. Dalam penelitian ini dilakukan dua evaluasi yaitu evaluasi formatif yang bertujuan untuk menilai produk yang dikembangkan berdasarkan uji validitas dan sumatif yang bertujuan untuk mengetahui efektivitas e-learning.

Hasil validitas model e-learning berbasis flipped classroom ini berdasarkan hasil uji penilaian atau evaluasi oleh (a) ahli isi mata pelajaran, (b) ahli desain pembelajaran, (c) ahli media pembelajaran, dan (d) siswa melalui uji coba perorangan, uji coba kelompok kecil, dan uji lapangan. Data hasil evaluasi dari para ahli beserta para siswa atau subjek uji coba produk diolah menggunakan analisis deskriptif kuantitatif dengan mencari skor rata-rata. Secara lebih rinci dapat dilihat pada Tabel 6. Hasil validitas pengembangan e-learning berbasis flipped classroom mendapat validitas baik dengan skor sekitar $84 \%$ 93\%sehingga akan membantu siswa dalam pembelajaran matematika kelas VIII di SMP. Melalui uji validitas produk pada ahli isi materi, ahli desain pembelajaran, ahli media pembelajaran, uji coba perorangan, uji coba kelompok kecil, dan uji coba lapangan mendapatkan masukan, saran, dan komentar serta telah mendapat revisi sesuai dengan saran dan komentar. Adapun masukan dan komentar yang diberikan oleh para ahli dapat dilihat pada Tabel 7. Berdasarkan saran dan komentar yang diberikan oleh ahli media pembelajaran telah dilakukan revisi demi kesempurnaan produk e-learning berbasis flipped classroom. Adapun saran dan masukan serta komentar dapat dilihat pada Tabel 8. Berdasarkan saran dan komentar yang diberikan oleh ahli mata pembelajaran telah dilakukan revisi demi kesempurnaan produk e-learning berbasis flipped classroom. Adapun saran dan masukan serta komentar dapat dilihat pada Tabel 9.

Tabel 6. Hasil Uji Validitas Produk

\begin{tabular}{cccc}
\hline No & $\begin{array}{c}\text { Subjek Uji Coba Media Permainan } \text { e-learning } \\
\text { berbasisi flipped classroom }\end{array}$ & Hasil Validitas & Keterangan \\
\hline 1 & Uji Ahli Isi Mata Pelajaran & $93 \%$ & Sangat Baik \\
2 & Uji Ahli Desain Pembelajaran & $89 \%$ & Baik \\
3 & Uji Ahli Media Pembelajaran & $94 \%$ & Sangat Baik \\
4 & Uji Coba Perorangan & $80 \%$ & Baik \\
5 & Uji Coba Kelompok Kecil & $87 \%$ & Baik \\
6 & Uji Coba Lapangan & $84 \%$ & Baik \\
\hline
\end{tabular}

Tabel 7. Perbaikan Produk Oleh Ahli Desain Pembelajaran

\begin{tabular}{clll}
\hline No. & \multicolumn{1}{c}{ Masukan, Komentar dan Saran } & \multicolumn{1}{c}{ Revisi } \\
\hline 1. & $\begin{array}{l}\text { Perlu dibuatkan petunjuk penggunaan untuk } \\
\text { Guru dan siswa. }\end{array}$ & $\begin{array}{l}\text { Menambahkan } \\
\text { penggunaan untuk guru dan siswa }\end{array}$ & video \\
\hline
\end{tabular}

Tabel 8. Perbaikan Produk Oleh Ahli Media Pembelajaran

\begin{tabular}{cll}
\hline No. & \multicolumn{1}{c}{ Masukan, Komentar dan Saran } & \multicolumn{1}{c}{ Revisi } \\
\hline 1. & $\begin{array}{l}\text { Gambar/foto pada halaman beranda agar } \\
\text { mencerminkan tema pembelajaran }\end{array}$ & $\begin{array}{l}\text { Memperbaiki halaman beranda dengan mengganti } \\
\text { gambar agar mencerminkan tema pembelajaran } \\
\text { mengganti huruf non kapital untuk teks uraian }\end{array}$ \\
2. $\begin{array}{l}\text { Gunakan huruf non kapital untuk teks } \\
\text { uraian }\end{array}$ & $\begin{array}{l}\text { Perlu dibuatkan buku petunjuk } \\
\text { penggunaan }\end{array}$ & Menambahkan buku petunjuk penggunaan \\
\hline
\end{tabular}

Tabel 9. Perbaikan Produk Oleh Ahli Mata Pelajaran

\begin{tabular}{clc}
\hline No. & \multicolumn{1}{c}{ Masukan, Komentar dan Saran } & \multicolumn{1}{c}{ Revisi } \\
\hline 1. & Hasil dari pembelajaran dengan e-learning & Tidak ada revisi \\
& berbasisis flipped classroom sudah sangat baik. & \\
& Tolong kembangkan kembali dengan materi \\
& yang lain
\end{tabular}


Hasil uji efektivitas e-learning berbasis flipped classroom ini berdasarkan hasil pre- tes, post-tes yang telah didapat. Data hasil uji efektivitas diolah menggunakan uji-t dengan mencari rata-rata siswa, Simpangan baku, $t_{\text {hitung, dan }} t_{\text {tabel. }}$ Secara lebih rinci dapat dilihat pada tabel berikut 10 . Hasil data tersebut dapat disimpulkan bahwa thitung sebesar 10,65 sedangkan tabel sebesar 2,00 dengan db sebesar 60 dan taraf signifikasi sebesar 5\%. Maka kesimpulan yang didapat adalah thitung $\geq$ dari tabel sehingga $\mathrm{H}_{0}$ ditolak dan $\mathrm{H}_{1}$ diterima, dengan begitu hipotesis terdapat perbedaan hasil pembelajaran yang signifikan setelah mengikuti pembelajaran e-learning berbasis flipped classroom pada siswa kelas VIII di SMP N 2 Singaraja pada tahun $2020 / 2021$ bisa diterima.

\section{Pembahasan}

Tujuan dari penelitian ini adalah untuk menganalisis hasil pengembangan itu e-learning berbasis fliped classroom pada mata pelajaran matematika dengan materi “Teorema Pythagoras" di kelas VIII SMP. Dalam proses pengembangannya e-learning berbasis flipped classroom ini telah mengalami beberapa uji riview dari para ahli serta telah diuji coba ke siswa melalui uji perorangan, uji kelompok kecil dan uji lapangan dan mendapatkan hasil baik. Selain itu e-learning berbasis flipped classroom telah melaksanakan uji efektivitas untuk mengetahui keefektifan e-learning ini. Adapun hasil kualifikasi baik dan hasil uji efektivitas pada e-learning berbasis flipped classroom ini dapat terjadi karena hal-hal sebagai berikut.

Proses dari Prosedur pengembangan pembelajaran e-learning berbasis flipped classroom ini menggunakan model ADDIE. ADDIE sendiri adalah salah satu model pengembangan yang sistematis dan terukur. Hal ini sejalan dengan pendapat dari (Tegeh \& Sudatha, 2019) yang mengatakan bahwa model ADDIE adalah model desain pembelajaran yang paling umum atau lazim digunakan dan dikembangkan secara sistematis. Pengembangan model ADDIE terbagi dalam lima tahapan yaitu: (1) analisis (analyze), (2) perancangan (design), (3) pengembangan (development), (4) implementasi (implementation), dan (5) evaluasi (evaluation). Pertimbangan-pertimbangan yang diambil dalam menentukan model pengembangan dalam membuat e-learning berbasis flipped classroom menurut (Mahadewi \& Sukmana, 2015) antara lain adalah (1) model harus dipilih sesuai kemampuan pengembang, (2) tahapan tidak terlalu rumit dan tidak sederhana, (3) model dapat membuat pengembang aktif dalam proses pembuatan program.

E-learning yang telah dikembangkan memiliki beberapa kelemahan dan keunggulan. Kelemahannya sendiri adalah siswa kurang dalam pendalaman materi karena materi yang diberikan langsung memalui e-learning tanpa mendapat penjelasan dari guru. Hal ini dikarenakan terjadinya virus korona yang mengakibatkan tidak terjadinya pembelajaran di kelas sebagai pendalaman materi. Kelemahan yang telah disampaikan tersebut akan diatasi dengan membuat solusi membuat siswa lebih aktif dalam proses pembelajaran dengan cara siswa lebih banyak menghubungi langsung guru, untuk menanyakan bagian-bagian yang belum dimengerti. Sedangkan untuk kelebihan e-learning ini adalah sangat mudah digunakan dalam pembelajaran, kedua adalah murid lebih mandiri dalam proses pembelajaran karena guru hanya sebagai fasilitator dalam pembelajaran. Dalam pembuatan $e$-learning ini juga telah menambahkan berbagai media yaitu handout dan video. Kedua media tersebut dibuat guna menunjang dalam proses pembelajaran e-learning berbasis flipped classroom. Video sendiri digunakan karena membuat siswa lebih memahami materi yang disampaikan.

Berdasarkan kajian lebih lanjut terdapat beberapa aspek yang mempengaruhi hasil validitas dan efektivitas pada e-learning berbasis flipped classroom yang telah dikembangkan. Aspek-aspek tersebut diantaranya, aspek isi pembelajaran dengan kualifikasi sangat baik mendapat persentase 93\%. Kualifikasi ini didapat karena, materi yang disajikan sudah sangat relevan dengan silabus sehingga mampu mempermudah peserta didik dalam melaksanakan proses pembelajaran dan meningkatkan motivasi belajar hal ini sejalan dengan (Muhammad, 2017) motivasi belajar yang tinggi akan sejalan dengan meningkatnya kemampuan belajar siswa tersebut sedangkan menurut (Romansyah, 2016) berpendapat bahwa relevansi antara materi dan silabus sangat penting bagi tercapainya suatu pembelajaran yang baik. Berdasarkan hasil paparan di atas maka dapat disimpulkan bawah e-learning berbasis flipped classroom yang telah dikembangkan valid sehingga bisa membantu dalam proses pembelajaran di kelas.

Ditinjau dari aspek desain pembelajaran, memperoleh kualifikasi baik dengan skor 89\%. Kualifikasi baik, hasil ini disebabkan karena memiliki kejelasan kurikulum yang di dalamnya termasuk identitas mata pelajaran, capaian pembelajaran, indikator, dan tujuan pembelajaran. Hal ini sejalan dengan pendapat (Muryani et al., 2013:134) bahwa kurikulum adalah suatu komponen yang sangat penting sebagai acuan dan indikator mutu pendidikan. Senada dengan pendapat tersebut menurut (Fujiawati, 2016) kurikulum ialah suatu rencana dalam memberi pedoman dalam pembelajaran. Kedua memiliki kejelasan metode yang di dalamnya termasuk isi materi dan keterpaduan materi sejalan dengan pendapat (Maesaroh, 2013:67) kejelasan metode yang digunakan sangat berpengaruh terhadap minat dan 
motivasi siswa itu sendiri. Sedangkan menurut (Hidayat et al., 2020:73) penggunaan metode pembelajaran yang tepat dan jelas akan lebih mudah untuk memancing atau menumbuhkan kegiatan pembelajaran siswa. Berdasarkan hasil paparan di atas maka dapat disimpulkan bawah e-learning berbasis flipped classroom yang telah dikembangkan valid sehingga bisa membantu dalam proses pembelajaran di kelas.

Berdasarkan hasil penilaian dari aspek ahli media memperoleh kualifikasi sangat baik dengan nilai 94 \%. Kualifikasi sangat baik ini disebabkan oleh beberapa faktor yaitu Tampilan, interaktivitas, dan kemanfaatan yang menarik. sejalan dengan hal tersebut menurut (Hanum, 2013) Tampilan, interaktivitas, dan kemanfaatan yang menarik akan memudahkan guru dalam menyusun dan memperjelas mekanisme $e$ learning yang dibuat. Senada dengan hal tersebut menurut (Herayanti et al., 2017) tampilan menerik akan lebih mudah menarik siswa dalam pembelahjaran. Selain hal tersebut terdapat juga faktor dalam media berupa video scibe dan handout hal tersebut terjadi karena video scibe dan handout telah mengikuti kaidah desain pesan. Sejalan dengan hal tersebut menurut Sudarma (Ningsih et al., 2018: 292) dalam pemilihan huruf menggunakan huruf yang mudah dibaca sesuai dengan karakteristik siswa, untuk font atau jenis huruf yang mudah terbaca adalah san serif ( tanpa sirip). Sedangkan menurut (Munawaroh et al., 2019) penggunaan desain pesan yang baik akan memudahkan siswa dalam memahami suatu materi. Berdasarkan hasil paparan di atas maka dapat disimpulkan bawah e-learning berbasis flipped classroom yang telah dikembangkan valid sehingga bisa membantu dalam proses pembelajaran di kelas.

Hasil uji coba perorangan, kelompok kecil, dan lapangan rata-rata memiliki kualifikasi baik dengan nilai rata-rata $84 \%$. Kualifikasi baik ini disebabkan oleh beberapa faktor yaitu pertama faktor visual dan audiovisual yang menarik. Hal ini sejalan dengan (Wina, 2011) video pembelajaran mengandung dua unsur yaitu audio dan visual, oleh sebab itu kemampuan video pembelajaran sangat baik dalam proses pembelajaran karena telah mengandung dua unsur sekaligus yaitu audio dan visual. Begitu juga dengan (Nurwahidah et al., 2013: 119) manfaat dari video pembelajaran adalah menumbuhkan motivasi dan pesan dari pembelajaran akan mudah disampaikan. Sedangkan menurut (Busyaeri et al., 2016: 126) manfaat lain dari video pembelajaran adalah penggunaannya bisa digunakan dalam semua materi baik itu IPA maupun IPS. kedua yaitu kesederhanaan media e-learning. Sajian sederhana akan cenderung mudah diingat ketimbang sajian yang mencolok hal ini sejalan dengan (Baharun, 2016) yang menyatakan bahwa media pembelajaran harus sesuai dengan kemampuan taraf berpikir siswa sehingga akan mempermudah masuknya konsep yang kompleks dan abstrak menjadi sederhana. Sedangkan menurut (Indra et al., 2018) media pembelajaran yang sederhana cenderung akan memudahkan siswa dalam pembelajaran. Berdasarkan hasil paparan di atas maka dapat disimpulkan bawah e-learning berbasis flipped classroom yang telah dikembangkan valid sehingga bisa membantu dalam proses pembelajaran di kelas.

Pada uji efektivitas yang telah diselenggarakan menggunakan pre-tes dan post-tes. Pre tes dan post tes sendiri digunakan untuk mengetahui seberapa jauh pemahaman siswa sebelum dan sesudah menggunakan e-learning. sejalan dengan pendapat tersebut menurut Piaget (Effendy, 2016: 83) Pre tes dan post tes adalah metode yang akan sangat membantu dalam proses asimilasi pengetahuan baru dan yang dimiliki oleh siswa. Sedangkan menurut (Mahfud et al., 2019) penggunaan pre tes dan post tes akan memudahkan guru dalam menentukan kemampuan siswa dalam belajarSetelah selesai melaksanakan uji pre-tes dan post-tes ke siswa dilanjutkan dengan menguji hasil tes dengan menggunakan rumus uji-t. Karena terjadinya virus korona pembelajaran e-learning berbasis flipped classroom tidak bisa maksimal, hal ini terjadi karena proses pembelajaran yang harus empat kali pertemuan diganti menjadi satu kali pertemuan. Akan tetapi cara untuk mengatasi hal tersebut siswa dituntut untuk lebih aktif menanya kepada guru, guna lebih mendalami lagi materi yang dipelajari. Selain hal tersebut e-learning berbasis flipped classroom juga telah diberi soal-saol latihan guna meningkatkan motivasi siswa dalam masa corona ini. Setalah melaksanakan pembelajaran di akhiri dengan post tes guna mengetahui seberapa berhasil pembelajaran e-learning berbasis flipped classroom ini. serta mendapatkan hasil bahwa Terdapat perbedaan hasil pembelajaran yang signifikan setelah mengikuti pembelajaran e-learning berbasis flippedd classroom pada siswa kelas VIII di SMP N 2 Singaraja pada tahun 2020/2021 dapat diterima atau $\mathrm{H}_{1}$ diterima.

Dari uji validitas dan efektivitas yang telah dilaksanakan terdapat kekurangan dalam proses penelitian ini yaitu, pada saat proses penelitian ini, terjadinya virus corona yang mengakibatkan pembelajaran e-learning berbasis flipped classroom tidak bisa maksimal, hal ini terjadi karena proses pembelajaran yang harus empat kali pertemuan diganti menjadi satu kali pertemuan. Akan tetapi cara untuk mengatasi hal tersebut siswa dituntut untuk lebih aktif menanya kepada guru, guna lebih mendalami lagi materi yang dipelajari. Selain hal tersebut e-learning berbasis flipped classroom juga telah diberi soal-soal latihan guna meningkatkan motivasi siswa dalam masa corona ini. 


\section{SIMPULAN}

Model e-learning berbasis flipped classroom adalah salah satu model pembelajaran e-learning yang cukup mudah diimplementasikan. Model ini akan membuat siswa bisa melaksanakan proses pembelajaran di mana pun dan kapan pun. Masa pandemi ini juga telah meningkatkan penggunaan model e-learning karena pembelajaran yang tidak bisa dilaksanakan di kelas. Selain hal tersebut model elearning berbasis flipped classroom ini sangat baik digunakan karena telah melewati tes validasi dari para ahli dan siswa, serta telah melewati tes efektivitas dengan hasil sangat efektif digunakan dalam pembelajaran.

\section{DAFTAR PUSTAKA}

Aeni, N., Prihatin, T., \& Utanto, Y. (2017). Pengembangan Model Blended Learning Berbasis Masalah pada Mata Pelajaran Sistem Komputer. Innovative Journal of Curriculum and Educational Technology, 6(2), 27-38. https://doi.org/10.15294/ijcet.v6i2.15642.

Agung, A. A. G. (2017). Metodologi penelitian kuantitatif (perspektif manajemen pendidikan). Singaraja: Universitas Pendidikan Ganesha.

Ahmed, M. M. H., \& Indurkhya, B. (2020). Investigating cognitive holding power and equity in the flipped classroom. Heliyon, 6(8), e04672. https://doi.org/10.1016/j.heliyon.2020.e04672.

Albab, S. U. (2020). Analisis kendala pembelajaran e-learning pada era disrupsi di SMK Terpadu AlIslahiyah Singosari Malang. Mudir: Jurnal Manajemen Pendidikan, 2(1). https://doi.org/10.36835/mudir.v2i1.105.

Amin, I., Yousaf, A., Walia, S., \& Bashir, M. (2021). What Shapes E-Learning Effectiveness among Tourism Education Students? An Empirical Assessment during COVID19. Journal of Hospitality, Leisure, Sport and Tourism Education, $x x x x$, 100337. https://doi.org/10.1016/j.jhlste.2021.100337.

Andel, S. A., de Vreede, T., Spector, P. E., Padmanabhan, B., Singh, V. K., \& Vreede, G. J. de. (2020). Do social features help in video-centric online learning platforms? A social presence perspective. Computers in Human Behavior, 113(April), 106505. https://doi.org/10.1016/j.chb.2020.106505.

Arnold-Garza, S. (2014). The flipped classroom teaching model and its use for information literacy

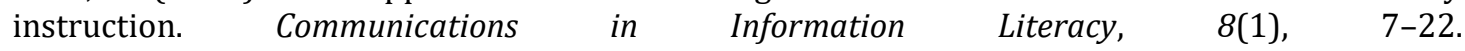
https://doi.org/10.15760/comminfolit.2014.8.1.161.

Arnott, L., \& Yelland, N. (2020). Multimodal lifeworlds: Pedagogies for play inquiries and explorations. Journal of Early Childhood Education Research, 9(1), 124-146. https://jecer.org/multimodallifeworlds-pedagogies-for-play-inquiries-and-explorations/.

Baharun, H. (2016). Pengembangan Media Pembelajaran Pai Berbasis Lingkungan Melalui Model ASSURE. Cendekia: Journal of Education and Society, 14(2), 231. https://doi.org/10.21154/cendekia.v14i2.610.

Busyaeri, A., Udin, T., \& Zaenudin, A. (2016). Pengaruh Penggunaan Video Pembelajaran Terhadap Peningkatan Hasil Belajar Mapel Ipa Di Min Kroya Cirebon. Al Ibtida: Jurnal Pendidikan Guru MI, 3(1), 116-137. https://doi.org/10.24235/al.ibtida.snj.v3i1.584.

Chiu Lin Lai, \& JenHwang, G. (2016). A self-regulated flipped classroom approach to improving students' learning performance in a mathematics course. Computers \& Education, 100(September), 126140. https://doi.org/10.1016/j.compedu.2016.05.006.

Darmawan, D. (2014). Pengembangan e-learning teori dan desain. Bandung: remaja rosakarya.

Effendy, I. (2016). Pengaruh Pemberian Pre-Test dan Post-Test Terhadap Hasil Belajar Mata Diklat HDW.DEV.100.2.a pada Siswa SMK Negeri 2 Lubuk Basung. Jurnal Ilmiah Pendidikan, 1(2), 81-88. http://dx.doi.org/10.30870/volt.v1i2.2873.

Elyas, A. H. (2018). Penggunaan model pembelajaran e-learning dalam meningkatkan kualitas $\begin{array}{llll}\text { pembelajaran. Jurnal Warta, } & \text { 56(04), }\end{array}$ http://jurnal.dharmawangsa.ac.id/index.php/juwarta/article/view/4.

Fujiawati, F. S. (2016). Pemahaman Konsep Kurikulum dan Pembelajaran dengan Peta Konsep Bagi Mahasiswa Pendidikan Seni. Jurnal Pendidikan Dan Kajian Seni, 1(1), 16-28. http://dx.doi.org/10.30870/jpks.v1i1.849.

Hanum, N. S. (2013). Keefetifan e-learning sebagai media pembelajaran (studi evaluasi model pembelajaran e-learning SMK Telkom Sandhy Putra Purwokerto). Jurnal Pendidikan Vokasi, 3(1), 90-102. https://doi.org/10.21831/jpv.v3i1.1584.

Herayanti, L., Habibi, H., \& Fuaddunazmi, M. (2017). Pengembangan Media Pembelajaran Berbasis Moodle pada Matakuliah Fisika Dasar. Jurnal Cakrawala Pendidikan, 36(2), 210-219. https://doi.org/10.21831/cp.v36i2.13077. 
Hidayat, A., Sa'diyah, M., \& Santi Lisnawati. (2020). Metode Pembelajaran Aktif Dan Kreatif Pada Madrasah Diniyah Takmiliyah Di Kota Bogor. Jurnal Pendidikan Indonesia, 09(01 Februari), 71-86. https://doi.org/https://doi.org/10.30868/ei.v9i01.639.

Hussein, E., Daoud, S., Alrabaiah, H., \& Badawi, R. (2020). Exploring undergraduate students' attitudes towards emergency online learning during COVID-19: A case from the UAE. Children and Youth Services Review, 119(August), 105699. https://doi.org/10.1016/j.childyouth.2020.105699.

Hwang, G. J., Wang, S. Y., \& Lai, C. L. (2020). Effects of a social regulation-based online learning framework on students' learning achievements and behaviors in mathematics. Computers and Education, 160, 104031. https://doi.org/10.1016/j.compedu.2020.104031.

Indra, I. G. W., Parmiti, D. P., \& Mahadewi, L. P. P. (2018). Pengembangan Media Pembelajaran Sederhana "Kotak Hitung" Pada Tema Lingkunganku Bidang Matematika Di Kelas II SD Negeri 2. In Jurnal Jurusan Teknologi Pendidikan (Vol. 9, Issue 2). http://dx.doi.org/10.23887/jeu.v6i1.20275.

Kaur, M., Goyal, P., \& Goyal, M. (2020). Individual, interpersonal and economic challenges of underemployment in the wake of COVID-19. Work, 67(1), 21-28. https://doi.org/10.3233/WOR203249.

Kim, S. H., \& Park, S. (2021). Influence of learning flow and distance e-learning satisfaction on learning outcomes and the moderated mediation effect of social-evaluative anxiety in nursing college students during the COVID-19 pandemic: A cross-sectional study. Nurse Education in Practice, 56(January), 103197. https://doi.org/10.1016/j.nepr.2021.103197.

Kkese, E. (2020). McGurk effect and audiovisual speech perception in students with learning disabilities exposed to online teaching during the COVID-19 pandemic. Medical Hypotheses, 144(July), 110233. https://doi.org/10.1016/j.mehy.2020.110233.

Lage-Cala, S., Folgueras-Díaza, M. B., Alonso-Hidalgoa, M., García-Menéndezb, D., \& Fernández-Garcíab, F. J. (2020). Investigation of the effectiveness of online learning tools for energy performance certificates preparation. Energy Reports, 6, 609-614. https://doi.org/10.1016/j.egyr.2019.09.034.

Latif, S. W. A., Matzin, R., Jawawi, R., Mahadi, M. A., Jaidin, J. H., Mundia, L., \& Shahrill, M. (2017). Implementing the Flipped Classroom Model in the Teaching of History. Journal of Education and Learning (EduLearn), 11(4), 374-381. https://doi.org/10.11591/edulearn.v11i4.6390.

Leonard, \& Mutia, I. (2013). Kajian Penerapan E-Learning Dalam Proses. Faktor Exacta, 6(4), 278-289. http://dx.doi.org/10.30998/faktorexacta.v6i4.239.

Looi, K. H. (2021). Data set of Malaysian Undergraduates' Challenges and Future Preference for E-learning During the COVID-19 Pandemic. Data in Brief, 38, 107450. https://doi.org/10.1016/j.dib.2021.107450.

Maesaroh, S. (2013). Peranan Metode Pembelajaran Terhadap Minat Dan Prestasi Belajar Pendidikan Agama Islam. Jurnal Kependidikan, 1(1), 150-168. https://doi.org/10.24090/jk.v1i1.536.

Mahadewi, L. P. P. (2006). Media video pembelajaran. Singaraja: Universitas Pendidikan Ganesha.

Mahadewi, L. P. P., \& Sukmana, A. I. W. I. Y. (2015). Text-based programming: Konsep dasar \& aplikasi pengembangan produk pendidikan. Yogyakarta: Graha Ilmu.

Mahfud, H., Adi, F. P., Atmojo, I. R. W., \& Ardiansyah, R. (2019). Peningkatan Kompetensi Evaluasi Pembelajaran Berbasis Teknologi Pada Guru SD Di Kota Surakarta. Jurnal Pendidikan Dasar, 7(2), 146-150. https://doi.org/10.20961/jpd.v7i2.35104.

Mishra, D. L., Gupta, D. T., \& Shree, D. A. (2020). Online Teaching-Learning in Higher Education during Lockdown Period of COVID-19 Pandemic. International Journal of Educational Research Open, 100012. https://doi.org/10.1016/j.ijedro.2020.100012.

Muhammad, M. (2017). Pengaruh Motivasi Dalam Pembelajaran. Lantanida Journal, 4(2). https://doi.org/10.22373/lj.v4i2.1881.

Muna, W., \& Hadisi, L. (2015). Pengelolaan Teknologi Informasi Dalam Menciptakan Model Inovasi Pembelajaran (E-learning). Jurnal Al-Ta'dib, 8(1), 117-140. http://dx.doi.org/10.31332/atdb.v8i1.396.

Munawaroh, F. Y., Riyanto, \& Warnaen, A. (2019). Pengaruh Desain Pesan Video Instruksional Terhadap Persepsi Petani Tentang Trichokompos. Komunikasi, XIII, 27-40. https://doi.org/10.21107/ilkom.v13i1.5214.

Muryani, S., Sulistari, E., \& Mirakaho, A. D. C. (2013). Identifikasi Kemampuan Mengembangkan Kurikulum Dalam Implementasi Ktsp Di Kalangan Guru SMK - Bm Di Kota Salatiga. Satya Widya, 29(2), 134. https://doi.org/10.24246/j.sw.2013.v29.i2.p134-144.

Ningsih, M., Suwatra, I. I. W., \& Pudjawan, K. (2018). Pengembangan Bahan Ajar Majalah dengan Model Hannafin dan Peck pada Mata Pelajaran IPA di SDN 5 Kampung Baru Singaraja. Jurnal EDUTECH Universitas Pendidikan Ganesha, 6(2), 285-295. http://dx.doi.org/10.23887/jeu.v6i2.20325.

Niswati, I., AK, D., Lestari, P., \& Gustyani. (2017). Hubungan antara metode online learning (e-learning) 
dengan motivasi berprestasi mahasiswa universitas "xx." Psibernatika, 5(1), 23-39. https: //journal.ubm.ac.id/index.php/psibernetika/article/view/527.

Nouri, J. (2016). The flipped classroom: for active, effective and increased learning - especially for low achievers. International Journal of Educational Technology in Higher Education, 13(1). https: //doi.org/10.1186/s41239-016-0032-z.

Nurwahidah, C. D., Zaharah, \& Sina, I. (2013). Media Video Pembelajaran dalam Meningkatkan Motivasi dan Prestasi MahasiswA. Rausyan FIKR: Jurnal Pemikiran Dan Pencerahan, 17(1), 118-137. http://dx.doi.org/10.31000/rf.v17i1.4168.

Oyedotun, T. D. (2020). Sudden change of pedagogy in education driven by COVID-19: Perspectives and evaluation from a developing country. Research in Globalization, 2(June), 100029. https://doi.org/10.1016/j.resglo.2020.100029.

Patricia, A. (2020). College Students' Use and Acceptance of Emergency Online Learning Due to COVID-19. International Journal of Educational Research Open, 100011. https: //doi.org/10.1016/j.ijedro.2020.100011.

Prawiladilaga, D. S. (2015). Prinsip desain pembelajaran (instructional design principle). Jakarta: Prenadan Media.

Purnama, S. (2013). Produk Pembelajaran Bahasa Arab. Literasi, 4(1), 19-32. http://dx.doi.org/10.21927.

Romansyah, K. (2016). Pedoman Pemilihan dan Penyajian Bahan Ajar Mata Pelajaran Bahasa dan Sastra Indonesia. Jurnal Logika, XVII(2), 59-66. http://jurnal.ugj.ac.id/index.php/logika/article/view/145.

Rusli, R., Rahman, A., \& Abdullah, H. (2020). Student perception data on online learning using heutagogy approach in the Faculty of Mathematics and Natural Sciences of Universitas Negeri Makassar, Indonesia. Data in Brief, 29, 105152. https://doi.org/10.1016/j.dib.2020.105152.

Sadikin, A., \& Hamidah, A. (2020). Pembelajaran Daring di Tengah Wabah Covid-19. Biodik, 6(2), $109-119$. https: //doi.org/10.22437/bio.v6i2.9759.

Sahu, P. (2020). Closure of Universities Due to Coronavirus Disease 2019 (COVID-19): Impact on Education and Mental Health of Students and Academic Staff. Cureus, 2019(4), 4-9. https://doi.org/10.7759/cureus.7541.

Setyoningsih. (2015). E Learning : Pembelajaran Interaktif Berbasis Teknologi. Elementary, 3(1), 39-58. https://journal.iainkudus.ac.id/index.php/elementary/article/view/1443.

Setyosari, P. (2015). Metode Penelitian Pendidikan dan Pengembangan. Prenadamedia Grup.

Subagia, I. M. (2017). Penerapan Model Pembelajaran Flipped Classroom Untuk Meningkatkan Prestasi Belajar Ipa Siswa Kelas X AP 5 SMK Negeri 1 Amalapura Tahun Ajaran 2016 / 2017. Lampuhyang, 8(2), 14-25. https://doi.org/https://doi.org/10.47730/jurnallampuhyang.v8i2.26.

Sukayanti, L. R., Sudarma, I. K., \& Jampel, I. N. (2018). Pengembangan Blended Learning Tipe Flipped Classroom Pada Mata Pelajaran Seni Budaya Kelas Xi. Jurnal EDUTECH Universitas Pedidikan Ganesha, 6(1), 134-146. http://dx.doi.org/10.23887/jeu.v6i1.20279.

Tegeh, I. M., \& Jampel, I. N. (2017). Metode penelitian pengembangan. Singaraja: Universitas Pendidikan Ganesha.

Tegeh, I. M., Jampel, I. N., \& Pudjawan, K. (2014). Model penelitian pengembangan. Singaraja: Universitas Pendidikan Ganesha.

Tegeh, I. M., \& Sudatha, I. G. W. (2019). Model-model desain pembelajaran: Seri buku teks teknologi pendidikan. Singaraja: Universitas Pendidikan Ganesha.

Wina, S. (2011). Perencanaan dan desain sistem pembelajaran. Jakarta: Kencana.

Zotov, V., Ibrahim, I., Petunina, I., \& Lazareva, Y. (2021). Engagement of Students in Data Visualization for the Purpose of E-Learning Improvement. International Journal of Emerging Technologies in Learning, 16(2), 46-63. https://doi.org/10.3991/ijet.v16i02.18745. 